\title{
SELECTED FACTORS OF THE SOCIALIZATION IMPACT OF COMPUTER GAMES AND THEIR CONTENT
}

\author{
Henryk Noga \\ Pedagogical University in Cracow, Poland
}

Henryk Noga. Selected Factors of the Socialization Impact of Computer Games and their Content

\begin{abstract}
Playing computer games is a very popular way of spending free time among teenagers. Taking a role of a hero in a game may be a source of behavioural patterns, may influence a system of values in life and may have an impact on teenagers attitudes towards others. It is important to examine what kind of features and values heroes represent and also what are the teenagers' preferences when it comes to the type of heroes in computer games.
\end{abstract}

Keywords: computer game, computer game hero, teenagers.

\section{Introduction}

Playing computer games is a very popular form of entertainment for young people. The true impact of computer games depends on many factors, among which is paramount the content of games and the time spent on playing a game (Shapiro, 2014; Przybylski, 2014; Sultanbayeva, 2013; Gentile et al., 2011; Braun - Gałkowska \& Ulik - Jaworska, 2002). Furthermore, the socialization impact of the games also depends on players' personal situation and features, including age, temperament and personality traits, quality of relationships in a family environment, peers, etc. The negative content of computer games cause numerous risks associated with the unsuccessful development of young people. Usually popular games among youth include elements of violence, Satanism and child pornography. Games with violent content increase the level of aggression of teenagers (Sultanbayeva, 2013). Computer games affect the attitudes of players (Feibel, 2006; Braun - Gałkowska \& Ulik -Jaworska, 2002). Ideas concerning the impact of computer games on the psyche of the youth are divided. On the one hand computer games popular among teenagers can be addictive and can stimulate aggressive behavior, on the other hand, regarding it, they are a modern form of entertainment full with colours (great graphics) and sounds that elicit positive and negative emotions, allowing to experience many exciting and dangerous adventures, shaping the components of the personality of a child or a teenager. 


\section{Description of the research}

Teenagers taking part in the research were 13 to 15 years old. A questionnaire consisting of 16 general questions was used (including 14 closed and 2 open type questions) and 13 specific questions (a questionnaire for teenagers playing computer games). Another questionnaire, dedicated to "not players" consisted of 9 general questions (including 7 closed and 2 open) and 13 with description. Young people in closed questions could make choice with two possible answers ,yes” or „no”.

Questions of the survey were arranged in the way, so it could be established whether the game affects education, and above all, the psyche of young people. The conducted research allowed to establish what games students often play (especially the ones containing violence) and whether they like it. The study also shows what attracts youth in the games, and that games can even be addictive (Noga, 2005; Żegnałek, 2006).

In order to achieve a more complete picture of the situation survey was conducted also for young people who do not play computer games. Its purpose was to show the perceptions regarding the ideal hero and to provide their opinion on preferable features and behavioural patterns presented by game characters. Another purpose was to compare the ideal heroes, and what is more important the features and behavioural patterns they represent, as seen by players and students who do not play computer games. Surveys were carried out in the countryside and in the city in order to demonstrate quantitative difference in terms of gaming.

Research in the form of surveys were conducted in April 2015 in two schools in the Brzesko commune. These were: the John Paul II Public Gymnasium in Jadowniki - first class students (23 persons) and the Queen Jadwiga Public Gymnasium Number 1in Brzesko - second class students (22 persons). On the time of filling in the questionnaire the attendance of pupils was $100 \%$.

The study was conducted based on a questionnaire, which was filled by 45 students in the first and in the second year of gymnasium. Surveys were completed by 23 first class students of high school in Jadowniki $(51.11 \%)$, including 12 girls (26.67\%) and 11 boys (24.44\%) and 22 second class high school students in Brzesko (48.89\%) in including 7 boys (15.56\%) and 15 girls (33.33\%). The data are shown in Tab. 1.

Among the respondents of high school students greater part are girls (60\%), then boys (40\%), both in rural and urban areas. A larger number of girls attend class II in Brzesko in comparison with the I class in Jadowniki. In contrast, class in Jadowniki has more boys by $8.88 \%$ than II class in Brzesko. The data are shown in Tab. 2. 
Table 1 Distribution of the study group for the village

\begin{tabular}{|l|l|l|l|l|l|l|}
\hline \multirow{2}{*}{ Class (Place) } & \multicolumn{2}{|c|}{ Girls } & \multicolumn{2}{c|}{ Boys } & \multicolumn{2}{c|}{ All } \\
\cline { 2 - 7 } & $\boldsymbol{\%}$ & quantity & \multicolumn{1}{c|}{ quantity } & \% & quantity \\
\hline I (Jadowniki) & 12 & 26,67 & 11 & 24,44 & 23 & 51,11 \\
\hline II (Brzesko) & 15 & 33,33 & 7 & 15,56 & 22 & 48,89 \\
\hline All & $\mathbf{2 7}$ & $\mathbf{6 0 , 0 0}$ & $\mathbf{1 8}$ & $\mathbf{4 0 , 0 0}$ & $\mathbf{4 5}$ & $\mathbf{1 0 0 , 0 0}$ \\
\hline
\end{tabular}

Table 2 Distribution of test group the on grounds of gender

\begin{tabular}{|l|l|l|}
\hline \multicolumn{1}{|c|}{ Gender } & \multicolumn{1}{|c|}{ Quantity } & \multicolumn{1}{c|}{$\%$} \\
\hline girls & 27 & 60 \\
\hline boys & 18 & 40 \\
\hline All & $\mathbf{4 5}$ & $\mathbf{1 0 0}$ \\
\hline
\end{tabular}

Surveys have been carried out anonymously. Students were asked the question „Do you play video games?” And depending on the response received appropriate questionnaire. Students who play computer games were given a survey prepared for the players, while the youth not playing games received a specially prepared questionnaire where they had to share their opinions on a number of topics regarding their perception of a game hero.

\section{Frequency of game playing}

Computers play a great role in almost every life domain of the contemporary world (Prauzer \& Ptak, 2014; Ptak \& Prauzer 2013; Gumuła \& Pytel, 2005; Pytel et al., 2012; Pytel \& Jaracz 2012). Entertainment is one of such life domain and playing computer games is a very popular way of spending free time among youngsters. Without a doubt, young people have a very good orientation in topics related to computer games. The phenomenon of intensive use of games among the younger generation increases from year to year. Frequency of game playing among teenagers is shown in Tab. 3 .

Some teenagers can spend every spare moment playing games. Sometimes they are willing to give up other forms of entertainment in order to have more time that can be spent playing computer games. Among the players, 18 students $51.43 \%$ declares playing games every day, including 6 students $(17.14 \%)$ of school in Jadowniki and 12 students $(34.29 \%)$ of gymnasium in Brzesko. Approximately $25.72 \%$ of adolescents play games several times per week. However, there are cases that the teenagers play once a week $(14.28 \%)$ or several times per month $(8.27 \%)$. It should be noted that none of the respondents did not play once a month. Youth prefer computer games as the best way of 
spending free time, both from the countryside and from the city. The amount of time that youth spent playing computer games is shown in Tab. 4.

Table 3 Frequency of game playing among young people

\begin{tabular}{|l|l|l|l|l|l|l|}
\hline \multirow{2}{*}{ How often do you play? } & \multicolumn{2}{c|}{$\begin{array}{c}\text { I class } \\
\text { gymnasium } \\
\text { (Jadowniki) }\end{array}$} & \multicolumn{2}{c|}{$\begin{array}{c}\text { II class } \\
\text { gymnasium } \\
\text { (Brzesko) }\end{array}$} & \multicolumn{2}{c|}{ All } \\
\cline { 2 - 8 } & quantity & \multicolumn{1}{c|}{ quantity } & \multicolumn{2}{c|}{ quantity } & \multicolumn{1}{c|}{$\%$} \\
\hline everyday & 6 & 17,14 & 12 & 34,29 & 18 & 51,43 \\
\hline few times per week & 4 & 11,43 & 5 & 14,29 & 9 & 25,72 \\
\hline once per week & 2 & 5,71 & 3 & 8,57 & 5 & 14,28 \\
\hline few times per month & 1 & 2,86 & 2 & 5,71 & 3 & 8,57 \\
\hline once in a month & 0 & 0 & 0 & 0 & 0 & 0 \\
\hline once in a while & 0 & 0 & 0 & 0 & 0 & 0 \\
\hline All & $\mathbf{1 3}$ & $\mathbf{3 7 , 1 4}$ & $\mathbf{2 2}$ & $\mathbf{6 2 , 8 6}$ & $\mathbf{3 5}$ & $\mathbf{1 0 0}$ \\
\hline
\end{tabular}

Table 4 Time youth spend on playing computer games

\begin{tabular}{|l|l|l|l|l|l|c|}
\hline $\begin{array}{c}\text { How much time do } \\
\text { you spent on } \\
\text { playing? }\end{array}$ & $\begin{array}{c}\text { I class gymnasium } \\
\text { (Jadowniki) }\end{array}$ & \multicolumn{2}{c|}{$\begin{array}{c}\text { II class gymnasion } \\
\text { (Brzesko) }\end{array}$} & \multicolumn{2}{c|}{ All } \\
\cline { 2 - 8 } & quantity & \multicolumn{1}{c|}{ quantity } & \% & quantity & \% \\
\hline less than 2 hours & 12 & 34,28 & 11 & 31,43 & 23 & 65,71 \\
\hline $2-4$ hours & 1 & 2,86 & 10 & 28,57 & 11 & 31,43 \\
\hline more than 4 hours & 0 & 0 & 1 & 2,86 & 1 & 2,86 \\
\hline All & $\mathbf{1 3}$ & $\mathbf{3 7 , 1 4}$ & $\mathbf{2 2}$ & $\mathbf{6 2 , 8 6}$ & $\mathbf{3 5}$ & $\mathbf{1 0 0}$ \\
\hline
\end{tabular}

Most respondents (65.71\%) say that they play less than 2 hours per day, including 12 teenagers (34.28\%) from the gymnasium in Jadowniki and 11 students from Brzesko. This is quite disturbing information. Approximately $31.43 \%$ of the respondents play games from 2 to 4 hours per day, which counts for higher risk associated with dependence of the young generation from the virtual world. Comforting is the fact that in the case of young people living in the countryside only 1 person plays from 2 to 4 hours. Unfortunately, in contrary, in town as many as 10 people $(28.57 \%)$ spends free time playing games from 2 to 4 hours during the day, and one person even more than that number of hours.

A number of research shows that the amounts of gameplay have a great impact on teenagers. The study carried out in Singapore on 3,000 students found that children who were more impulsive and less comfortable with other children were more likely to become pathological gamers (Gentile at al., 2011). After two years, the gamers, who played about 31 hours a week, were more likely to suffer from anxiety, depression and social phobias then students who played less 
(19 hours a week). Heavy gamers also seemed to perform worse at school then those who spent less time playing computer games. Przybylski (2014) conducted a study of almost 2,500 teenagers. It showed that children who spent more than half their free time playing games had more adjustment problems, showed lower levels of prosocial behaviour and life satisfaction.

\section{The heroes of the game and their impact}

A computer game hero is a central character appearing in the game, observed on both the TV or a computer screen, directed by person who plays. The presence of the hero (or several heroes) is usually necessary for playing a computer game.

The main character can be represented in the game in two ways. It can be seen from an external perspective (eg. through a side view, the view from a third person perspective), where one can see his face and his whole body and how he/she moves around in the game. In recent games hero is presented very realistically, his moves are very natural, smooth. For example, when he/she speaks, his/her lips are moving. The second way of presenting the hero is the view from the first person perspective (FPP). Then the main character is not shown on the screen (sometimes the face of the hero is presented in the corner of the screen), but one can see what the hero holds in his/her hands (and it is mostly weapon). Player looks at the virtual reality through the eyes of the chosen character that he/she controls. This way of presenting characters leads to a strong player identification with the hero. Increasingly, there are also games that allow the use of both presentations hero character in a computer game (eg. „MDK”, „Dungeon Keeper”). Players can choose between the view from the perspective of first and third person.

The basic action of hero in ,aggressive" computer games is fighting. Frequently hero fights on the side of good, that is, acts as a defender of the weak and vulnerable characters or has a mission of saving others from danger. There are also games where the player can choose between fighting for the sake and in the name of evil. For example, in the game „Dungeon Keeper” players can take a role of the evil dungeon guard who builds their underground kingdom, prisons, torture chambers and abusing the subordinates. In another game, „Grand Theft Auto," players take on the role of criminal and violent gangster. Actions like stealing cars, throwing the driver from the can, running over pedestrians and causing many road traffic collisions are the ones for which player receives even more points.

Heroes of ,aggressive" computer games are usually male characters and female appear rarely. One of the best-known computer game female hero is Lara Croft. In many games (eg. Feature), player can select the form of the chosen 
character and other features of hero appearance. Computer hero may thus have different characteristics and abilities. In games containing violence is the most common warrior, a knight fighting with different opponents. He/she usually works alone, but sometimes is assisted by other characters.

The hero appearing in the ,aggressive” computer games is usually a physical person. With a form of superhuman he/she has an unusual physical strength. He/she has the ability to use various types of weapon and spells. The battle is often a cruel, uncompromising and does not count with the principles of fair play. This type of a hero kills and destroys everything that appears on his path, (especially in shootings 3D). His/her goal is to defeat opponents and achieve a victory at all costs. The most effective way to achieve this goal and solve all problems is violence and destruction.

An analysis of the computer hero shows that a dominant characteristic is his/her attitude "to have" towards other people and realities (in opposite to the "to be" attitude, that is preferred in the process of conscious bringing up children). State of materials goods (of weapons, money, conquered lands) it is a common factor and a major determinant of success and self-esteem. The hero is focused to earn money, gain ,extra lives” and acquire more and more material goods.

Desire to be the governance and to dominate over others leads to multiple cross-hero moral norms and contempt for the fundamental human values. The main (sometimes the only) criterion of his/her action is the effectiveness understood as a positive and valuable outcome mostly for the hero, not other characters around. Evaluation of the situation and the choice of the behaviour depends on the desired outcomes. Therefore, consequences that are good for the hero are considered as a value.

A hero is rarely friendly or concerned about others and their lives. If he/she happens to be worried about others, it is only when it is not in conflict with his plans. A hero does not establish a close relationships with other characters, but presents utilitarian attitude towards them. Personal contacts and talks do not serve building the deeper bonds with others, but are aimed primarily to obtain useful information or items necessary for further tasks. A hero often does not respect the freedom and dignity of another hero. He/she often ignores, degrades others, and even forces to certain activities, uses, and shows a lack of respect for their lives.

Computer hero is focused exclusively on himself/herself and his/her issues and does not pay attention to the needs and expectations of others, unless he/she can see some benefits for himself/herself. Often is not being able to accept others point of view. A hero usually does not express empathy, compassion for the other characters. Seeks primarily on self-interest, considering that this is the 
right action, regardless of whether this is in conflict with the interests of others, or not.

There are games where the characters would combine computer selfless love, respect or friendship. Friendship and love are instead portrayed as something impermanent, conditioned by personal benefits. There is no place for kindness towards others in violent video games, because such behaviour will not result in progress in the game and lead to a quick death of a hero. The rules of „aggressive" computer games therefore do not provide choices other than selfish, aggressive behaviours and forcement. The most effective way of solving problems in the games is applying the law of the jungle. That is why the heroes in computer games express an attitude opposite to love and friendship. Others are perceived as threats, and their life have no value for the hero, so heroes are mostly annihilators.

In the virtual world of computer games there are no prohibitions arising from the moral law. Point of reference and a criterion of good and evil is the effectiveness in achieving the goals.

The thrill of playing games, of becoming somebody who has the control over his life and often lives of others can lead to adoption of behavioural patterns from the game. Heroes' behaviour may become a significant determinant of the teenage behaviour in the real world. Especially dangerous behaviour patterns are aggression and competition, focus on self and his/her success without taking into account feelings and interests of others, often weak and vulnerable. Very important, and at the same time conducive to the transmission of behaviour are network games, in which players take on the role of characters, create their CVs and modify them. It is a situation which creates opportunities to learn how to manage their own lives and make difficult choices. An example of this type of game is called shooters - FPS (First Person Shooter) games, adventure games - TPP (Third Person Perspective), as well as roleplaying games - RPG (Role Playing Games).

Table 5 Heroes and heroines - gender collation

\begin{tabular}{|c|c|c|c|c|c|c|}
\hline \multirow{3}{*}{$\begin{array}{l}\text { Who's your favorite } \\
\text { computer game hero? }\end{array}$} & \multicolumn{6}{|c|}{ „Players” } \\
\hline & \multicolumn{2}{|c|}{ Girls } & \multicolumn{2}{|c|}{ Boys } & \multicolumn{2}{|c|}{ All } \\
\hline & quantity & $\%$ & quantity & $\%$ & quantity & $\%$ \\
\hline Female & 9 & 25,71 & 3 & 8,57 & 12 & 34,28 \\
\hline Male & 8 & 22,86 & 11 & 31,43 & 19 & 54,29 \\
\hline $\begin{array}{l}\text { no information about } \\
\text { gender }\end{array}$ & 1 & 2,86 & 3 & 8,57 & 4 & 11,43 \\
\hline All & 18 & 51,43 & 17 & 48,57 & 35 & 100 \\
\hline
\end{tabular}


Gender of the main character of the game depends on the „player" choice, which is presented in Tab. 5. Games give the opportunity to choose different features and abilities of the character. Most common are: bravery, strength, charisma, speed. Some students prefer strong, some fast, others resistant heroes.

Girls state they prefer to play computer games in which the main character is a female, 9 respondents $(25.71 \%)$ has given such answers. However, girls $(22.86 \%)$, prefer games in which the main role is played by a male. In contrast, the majority of boys $(31.43 \%)$ answered that their gaming is dominated by males, and only 3 boys $(8.57 \%)$ pointed a female as the main character they choose when playing a game. Testimonials of ,players” regarding the choice of character vary. In turn the „not players” would like to enjoy the games in which the heroes are mostly males, so the boys responded, the girls stated that they would prefer to see a female in the main role. Data supporting the fact that gender of ,not players" had a big impact on choosing a gender of a game hero is shown in Tab. 6 and Fig. 1.

Table 6 Heroes and heroines preferences among „not players”

\begin{tabular}{|c|c|c|c|c|c|c|}
\hline \multirow{3}{*}{$\begin{array}{l}\text { Would you rather a hero } \\
\text { or a heroine in a } \\
\text { computer game? }\end{array}$} & \multicolumn{6}{|c|}{ „Not players" } \\
\hline & \multicolumn{2}{|c|}{ Girls } & \multicolumn{2}{|c|}{ Boys } & \multicolumn{2}{|c|}{ All } \\
\hline & quantity & $\%$ & quantity & $\%$ & quantity & $\%$ \\
\hline Female & 8 & 80 & 0 & 0 & 8 & 80 \\
\hline Male & 0 & 0 & 1 & 10 & 1 & 10 \\
\hline $\begin{array}{l}\text { no information about } \\
\text { gender }\end{array}$ & 1 & 10 & 0 & 0 & 1 & 10 \\
\hline All & 9 & 90 & 1 & 10 & 10 & 100 \\
\hline
\end{tabular}
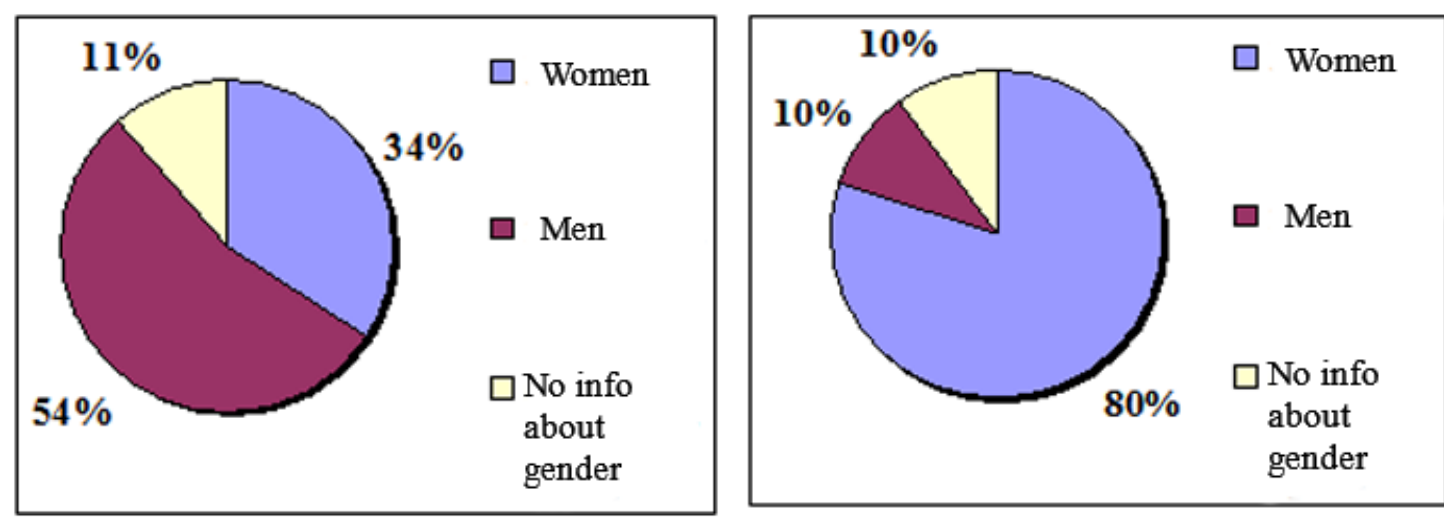

Figure 1 Preferable gender of hero among "not players"

Roles and features of the game hero indicated by the ,players" are presented in the fig. 2 . The research shows that the prime activities of computer games characters are: winning, destroying, taking risk, fighting and competing. 
According to the ,players" character that plays a major role in the computer game has a wide experience, fights at all costs, likes competition, etc. - these findings are compatible with other research (Laniado \& Gianfilippo, 2006).

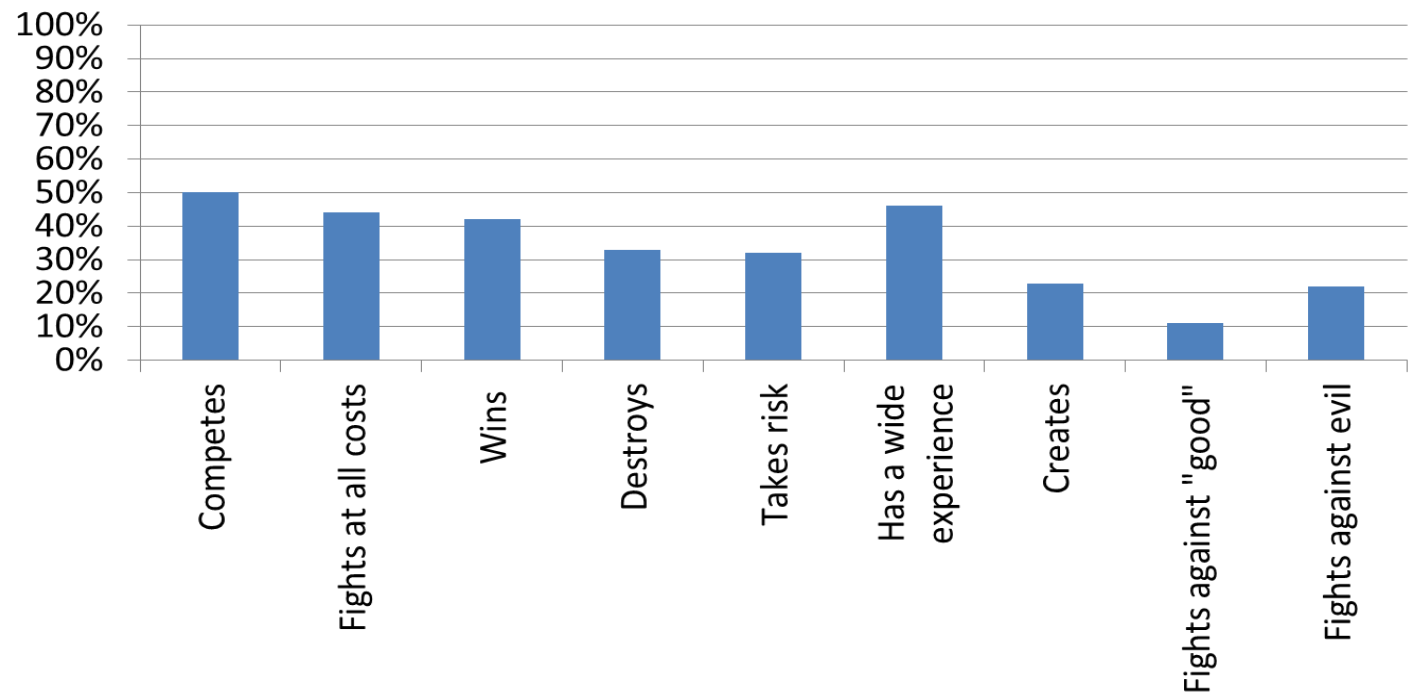

Figure 2 Preferable roles and features of heroes by "players"

Opinions of „not players” (students who claim not playing games) are very different and are presented in Fig. 3. The young generation that does not benefit from computer games imagines believe that a main character is honest, fights against evil and supports good. The „not playing young people „, would like to have a hero who wins, does not fight at all costs and takes risk. In their opinion the main character of a computer game has much more positive features then a hero described by players.

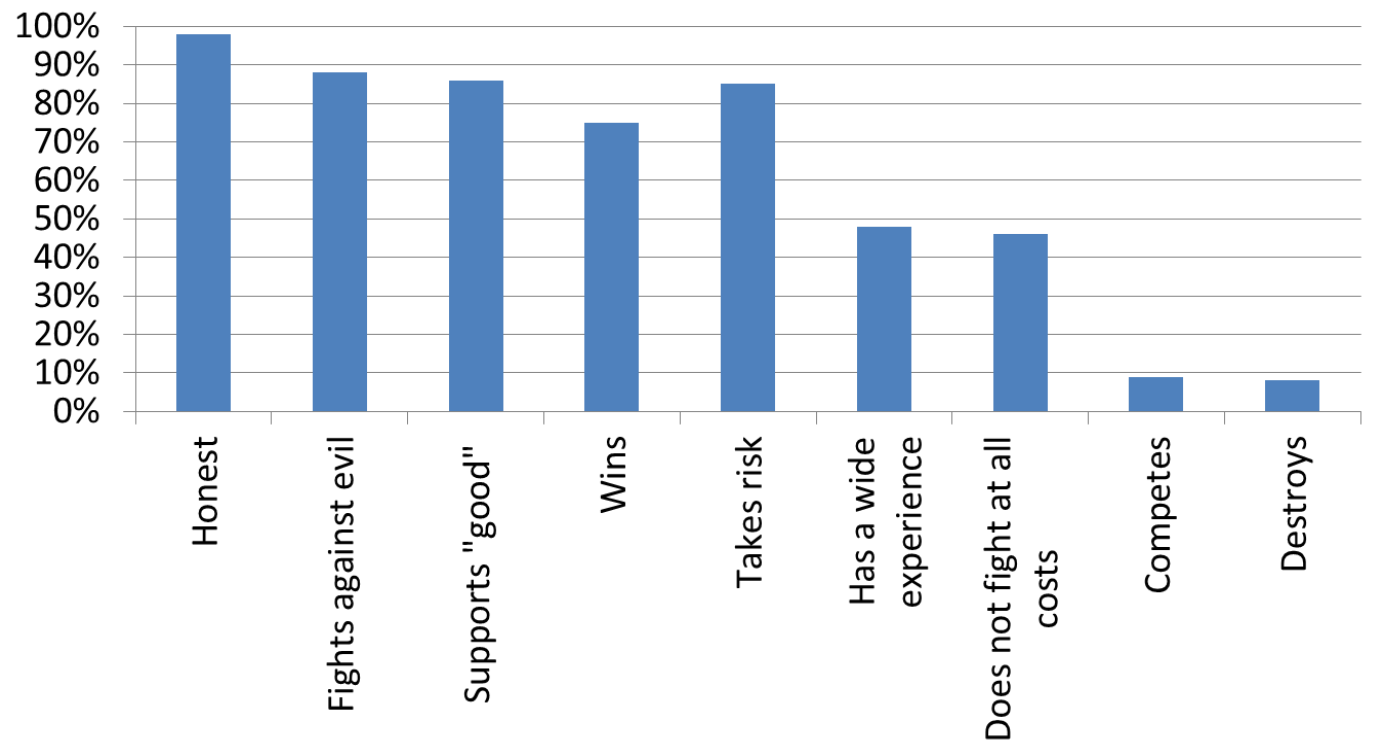

Figure 3 Roles and features of perfect heroes (by "not players") 


\section{Conclusion}

The research shows that teenagers spend a lot of their free time playing computer games. What is more, very popular computer games are those that contain a lot of violence and aggression. The main criterion of hero's actions is the effectiveness understood as a positive outcome for himself/herself. Game hero usually does not take into account feelings or interests of other characters and represents utilitarian attitude towards others. Preferable features of heroes marked by players are very different from those pointed by not players.

\section{References}

Braun-Gałkowska, M., \& Ulik-Jaworska, I. (2002). Zabawa w zabijanie. Lublin: Wyd. Kaudium

Feibel, T. (2006). Zabójca $w$ dziecinnym pokoju. Warszawa: Instytut Wydawniczy PAX.

Gentile, D.A., Choo, H., Liau, A., Sim, T., Li, D., Li, D., Fung, D., \& Khoo, A. (2011). Pathological Video Game Use Among Youths: A Two-Year Longitudal Study. Pediatrics, Volume 127, Number 2, pp 319-329.

Gumuła, S., \& Pytel, K. (2005). Kształtowanie parametrów strugi powietrza za wentylatorem osiowym w kanale kwadratowym iw przestrzeni otwartej za kanałem. Mechanics AGH, University of Science and Technology, 24, s. 246-251.

Laniado, N., \& Gianfilippo, P. (2006). Gry komputerowe i telewizja. Kraków: Wyd. eSPe.

Noga, H. (2005). Bohaterowie gier komputerowych - implikacje pedagogiczne. Kraków: nakładem autora.

Prauzner, T., \& Ptak, P. (2014) Analiza parametrów pracy wybranych czujników pola magnetycznego. Przeglad Elektrotechniczny, nr 12/2014, s.273-276.

Przybylski, A. (2014) Electronic Gaming and Psychosocial Adjustment. Pediatrics, Volume 134, Number 3, pp 1-7.

Ptak, P., \& Prauzner, T. (2013). Badania czujników detekcji zagrożeń w systemach alarmowych. Przeglad Elektrotechniczny, 2013 nr 10/2013, s. 274-276.

Pytel, K., Jaracz, K., \& Gumuła, S. (2012). An impact of chosen construction parameter and operating conditions on the quality of wind turbine energy generation. $13^{\text {th }}$ International Carpathian Control Conference (ICCC), Rzeszów, s. 592-595.

Pytel, K., \& Jaracz, K. (2012). Analiza możliwości wykorzystania wybranych hybrydowych układów pozyskiwania energii ze źródeł odnawialnych. Przegląd Elektrotechniczny, 2012 nr 9/2012, s. 243-249.

Shapiro, J. (2014). A Surprising New Study on How Video Games Impact Children. Forbes, Tech 8/27/2014, pp 19-23.

Sultanbayeva, L., Shyryn, U., Minina, N., Zhanat, B., \& Uaidullakyzy, E. (2013). The Influence of Computer Games on Children's Aggression in Adolescence. Procedia Social and Behavioral Sciences, 82 (2013), pp 933-941.

Żegnałek, K. (2006). Przyczyny zachowań agresywnych dzieci i młodzieży w wieku szkolnym. Edukacja, nr 1, s. 21-25. 